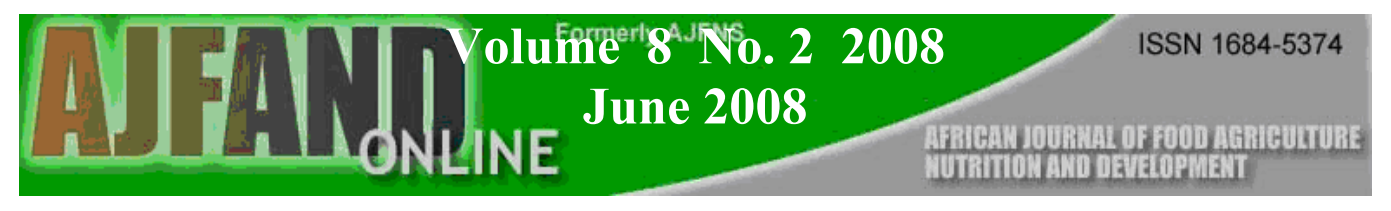

\title{
IMPACT OF FOOD AID ON \\ SMALLHOLDER AGRICULTURAL DEVELOPMENT IN SWAZILAND
}

ML Mabuza ${ }^{1^{*}}$, Taeb $M^{2}$ and $M$ Endo $^{3}$

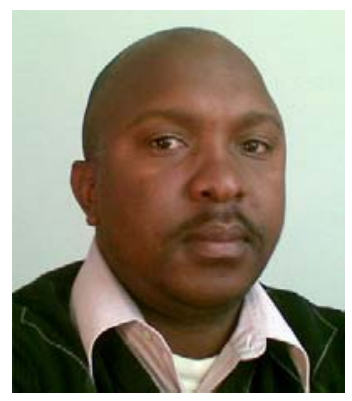

Majola Mabuza

Corresponding Author Email: 1mabuza@yahoo.co.uk

${ }^{1 *}$ Majola L. Mabuza - Economic Planning and Analysis Section, Ministry of Agriculture \& Cooperatives P O Box 162, MBABANE, Swaziland. Tel: +268 4042731. Fax: +268 4221370

${ }^{2}$ Mohammed Taeb - United Nations University, Institute of Advanced Studies (UNU/IAS) International Organisation Centre, 6F Pacifico - Yokohama 1-1-1 Minato Mirai Nishi - ku YOKOHAMA 220-0012, Japan. Tel: +81-45-221-2300. Fax: +81-45-221-2302. E-mail: taeb@ias.unu.edu

${ }^{3}$ Mitsungi Endo - Advanced Social and International Studies. Graduate School of Arts and Sciences University of Tokyo, Komaba. 3-8-1 Komaba Meguro-ku. TOKYO 153-8902 Tel: +81-3-5454-6490. Fax: +81-3-5454-4339 Email: endo@waka.c.u-tokyo.ac.jp 


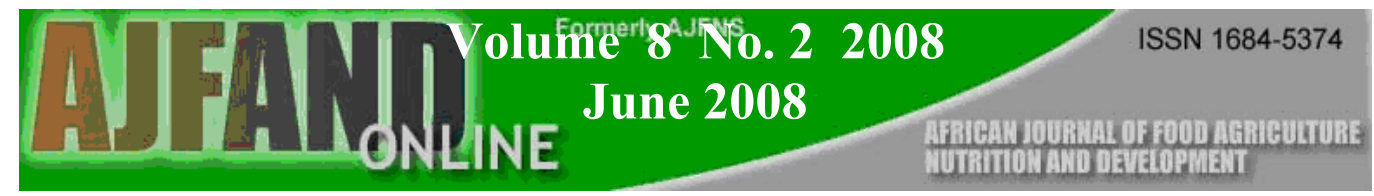

\begin{abstract}
Food aid is a widely debated development topic and such debates have given rise to the existence of two schools of thought regarding its resultant effects. The general belief is that food aid has disincentive effects, whereas the counter belief is that food aid instead comes with contributional effects to agricultural development. For the past five production seasons, cereal food aid deliveries have featured prominently in the coverage of Swaziland's maize gap following Government's appeal to the international community to assist with the impact of drought on the country's food production. This study examined whether food aid has affected agricultural production of smallholder farmers in Swaziland who ironically constitute a larger proportion of food aid beneficiaries in the occurrence of drought. The study was based on empirical evidence from a representation of 240 smallholder farming households identified from the Lowveld Cattle \& Cotton and the Highveld Maize \& Cattle Food Economy Zones. Data were collected using multiple stage and random sampling techniques and analysed using Chi-square, logistic regression and multiple regression. Key findings of the study reflected that there is no significant dependence between food aid and agricultural production at household level. Agricultural production is not affected by receiving food aid per se, however, the mode of distribution to beneficiaries (free food aid) remains a cause for concern as it is likely to influence production decisions of beneficiaries. Further analysis revealed that the identification criteria are inconsistent within the study area, reflecting the necessity to improve on targeting. The issue of targeting needs to be further investigated as it could give a broader picture with regards to errors of inclusion and exclusion. Such a study would be suitable to examine the efficiency of food aid in the country. It is recommended that the Government of Swaziland considers the formulation of a food security policy that will address food security issues in a wholistic manner rather than to rely on a food aid programme that is meant for short term interventions when infact the effects of drought appear to be perpetual in the country.
\end{abstract}

Key words: Food Aid, Agricultural Production, Impact

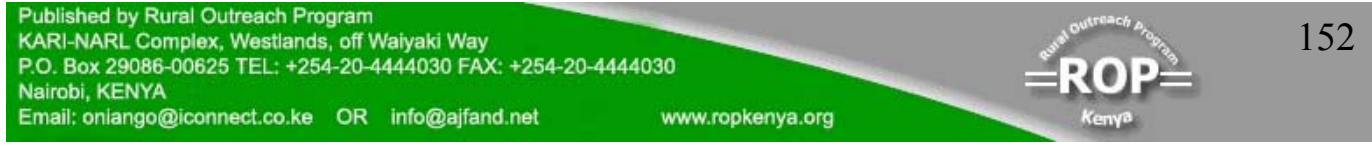




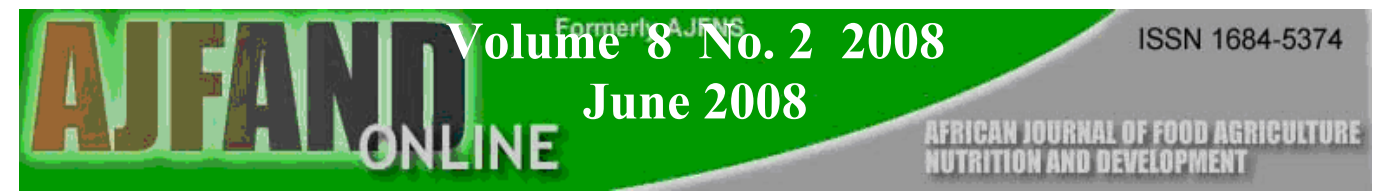

\section{INTRODUCTION}

Food aid has served as a major tool for the international community in improving food access and reducing suffering from emergency conditions in low income countries [1]. Changes in the level and use of food aid are capable of playing an important role in reducing the food gap, particularly in sub Saharan Africa (SSA) where estimates reflect that the quantity of food needed to maintain consumption will increase from 13 million to 17.4 million tons in 2009 [2].

While food aid has served a valuable function in cases of disaster, when normal supply channels are disrupted, it has in many cases had undesirable consequences in developing economies [3]. This is mainly because food aid deliveries tend to increase supply faster than they stimulate demand, thereby depressing food prices received by country producers and traders. Disincentive effects on agricultural production may result from farm level responses to price reduction caused by increased food supplies and dependency effects at the Government level that reduce incentives to emphasize agricultural development in central Government policy [4,5] . There is also a possibility that food aid would change consumer preferences towards imported and away from domestically produced staples [6].

On the contrary, some studies that were conducted in SSA found that food aid has a significant positive effect on food production [7,8]. They revealed that any disincentive induced by the additional supply of food tends to be offset by the positive effects. One possible explanation for this is that countries that enjoy a relative abundance of regular food aid can use the resources made available through reduced food imports to invest more in the agricultural sector.

This study was, therefore, conducted for the purpose of analyzing the effect of food aid on Swaziland's smallholder agricultural production at household level. Specifically, the objectives of the study were:

i) To analyse the relationship between food aid and agricultural production;

ii) To examine the food aid distribution criteria, and lastly;

iii) To quantify the effect of receiving food aid by farming households on agricultural production.

Swaziland in the past 5 - 10 years has been severely affected by drought and almost a third of the country's population who rely on rainfed agriculture have been the worst affected [9]. The reasons for the dire situation are manifold and include poor technology and low productivity, lack of appropriate inputs, particularly high yielding seed varieties and fertilizers, declining soil fertility, poor agricultural support services, and government policies which have, in general, not been fully supportive to the agricultural sector.

In the past five years, free cereal food aid deliveries have featured prominently in the coverage of the country's maize gap and this follows Government's appeal to the international community to assist with the impact of drought and erratic rains on the country's food production. The HIV/AIDS pandemic, which according to the Southern 
African Development Community (SADC) is $38.8 \%$, has increased the severity of the crises by depleting the ability of communities to participate in labour intensive food production [10]. Fields have remained fallow for a number of consecutive years and livestock numbers continue to dwindle. The availability of donor food, particularly maize, which happens to be the country's staple crop, has somehow discouraged some farming households from taking advantage of the rains that are sometimes received late in the growing season.

Considering the extent of negative externalities attributed to food aid, this study expected to produce empirical evidence that would, to some extent, identify the thin line that currently exists between the advantages and disadvantages attached to food aid in Swaziland, particularly on the smallholder agricultural sector. Issues of disincentive and contributional effects of food aid have been debated and analysed since the early 1960's by numerous researchers without definite conclusions [11]. Related studies that are specific to Swaziland are relatively scarce, and as a consequence, premature conclusions are often drawn on the basis of quite limited evidence.

Findings from this study will contribute towards the development of short and long-term policy interventions aimed at fostering food security sustainability in the country.

\section{METHODOLOGY}

The study was conducted in the form of a survey and was based on primary data gathered from individual farming households using a structured questionnaire. For the purpose of this study, a smallholder farmer is defined as one who produces either under rain fed or irrigation conditions but on a land resource that is ten hectares or less [12].

The sampling frame used in the study was based on existing Food Economy Zones (FEZ) in the country. These are relatively homogenous geographic areas with regards to sources of food and income. For the purpose of effective comparison, the study incorporated two FEZs with extreme food security parameters. The two FEZs are the Lowveld Cattle \& Cotton (LCC) FEZ (characterized by $80-90 \%$ population with food deficit) and the Highveld Cattle $\&$ Maize (HCM) FEZ (characterized by $0-10 \%$ population with food deficit) [13]. A sample of 240 households were interviewed having been identified using multiple stage (or cluster) sampling and random sampling techniques [14]. From the two FEZs, all local administration centres falling within each zone were identified from which a random sample of four administration centres per FEZ were picked, bringing the total to eight centres. Since each centre is made up of a number of chiefdoms, a random sample of three chiefdoms was made and from each chiefdom a total of ten households were randomly picked and interviewed. This leads to a total of 30 respondents per local administrative centre bringing the number of respondents to 120 households per FEZ and 240 households overall.

Four research assistants were engaged for data collection. Prior to that, the study had to be introduced to local administrators and extension officers, who accompanied the research assistants throughout the data collection exercise. Respondents participated in the study willingly and were assured of the highest level of confidentiality regarding the exposure of information contributed towards the implementation of the study. Information sourced from

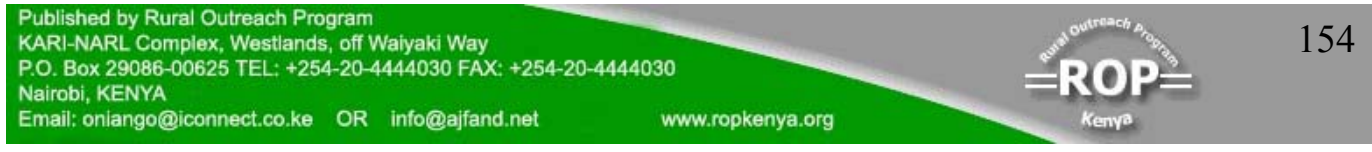




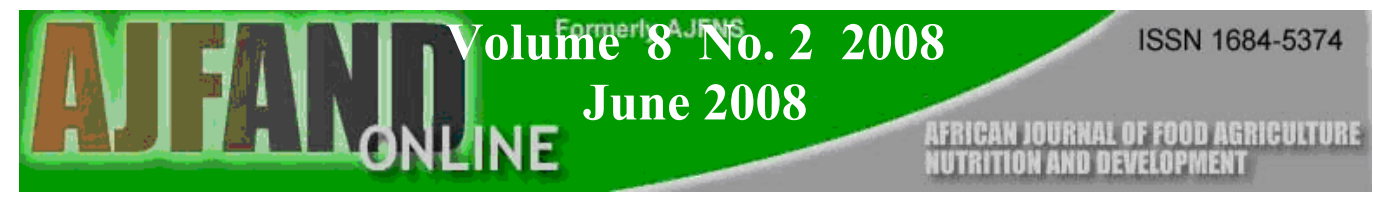

the respondents included household demography, agricultural production, household income and expenditure, asset ownership and food aid distribution.

The chi-square was used to determine the dependence between food aid and agricultural production, whereas binary logistic regression was used to examine the distribution criteria amongst farming households. To quantify the impact of food aid on agricultural production, the study employed a multiple regression analysis. All types of analyses were done using Statistical Package for Social Science (SPSS), version 11.0. The chi-square has been used in past studies, such as Thamaga-Chitja et al, to study the impact of maize storage on rural household's food security [15]. In particular, the chi-square was used to analyse the relationship between storage practices and food security indicators in KwaZulu-Natal. Zegeye et al. used both the logistic regression and chi-square to determine the factors affecting adoption of improved maize varieties and chemical fertilizer use [16]. The multiple regression model was used by Demeke to analyse the food aid impact at macroeconomic and at household levels in Ethiopia [17].

In this study, the chi-square tool of analysis was employed to test for independence between a proxy variable for food aid availability in year $\left(\mathrm{t}_{-1}\right)$ and three other variables, which could be aligned with household agricultural production. These are, land cultivation in year $(\mathrm{t})$, production of at least one food crop in year $(\mathrm{t})$, and the production of at least one cash crop in year $(\mathrm{t})$. The logistic regression was used to determine the farm and farmer characteristics that influence the likelihood of a farming household to receive food aid. For effective comparison, the data was analysed according to the two FEZs with the assumption that food aid should be received by households who exhibit certain similar characteristics irrespective of which FEZ they fall under. The dependent variable was dichotomous, meaning that a household in each zone was either a recipient of food aid or a non-recipient in the year $\left(\mathrm{t}_{-1}\right)$. The dependent variable was regressed against a combination of farm and farmer variables, which are postulated by literature as having a major influence in the identification process. Farm characteristics included; variables on whether a household was relying predominantly on dryland or irrigated farming. Farm characteristics included; age of household head, education of household head, occupation of household head, number of people residing within the household, capacity of household to educate all children within school attending age bracket, and wealth status of the household. A wealthy household is one that owns assets, which are otherwise considered luxury items for a typical smallholder farming household residing in the rural areas of Swaziland.

The multiple regression analysis was used to determine the effect of receiving food aid by farming households on household agricultural production. The dependent variable used was the average hectarage under food production in the current year $(\mathrm{t})$. Explanatory variables included the following; gender of household head, food aid type in year $\left(\mathrm{t}_{-1}\right)$, months survived on harvested produce, number of members living within household, occupation of household head, education level of household head, land size owned and the frequency of contact between household and extension officers.

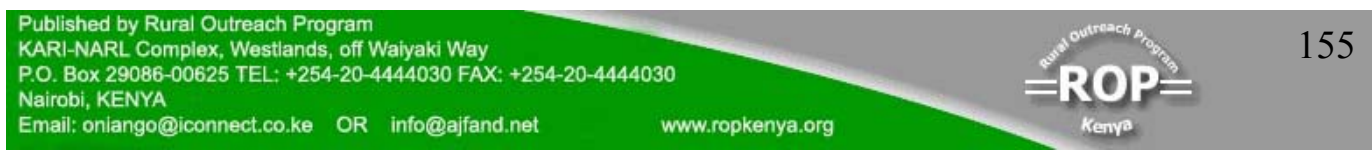




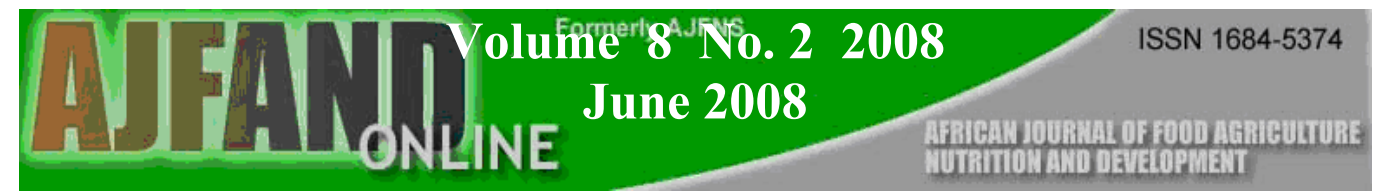

\section{RESULTS}

During data cleaning, it was discovered that three questionnaires were erroneously filled in, hence the number of entered questionnaires, which subsequently formed part of the analyses came down to 237 .

\section{Dependency between food aid and agricultural production}

The results in Table 1 reflect that the cultivation of land by households in either FEZ, the production of food crops and/or cash crops in year $(\mathrm{t})$ are statistically $(\mathrm{P}>0.1)$ independent of food aid availability (receiving food aid) in year $\left(\mathrm{t}_{-1}\right)$.

\section{Household eligibility to receive food aid}

The results in Table 2 reflect that the model has an acceptable level of correct prediction of $73.5 \%$ of overall outcomes. The Hosmer-Lameshaw Goodness of fit shows a value of 0.778 , which is above the critical 0.05 . Significant variables were found to be the number of household members $(p<0.1)$, wealth status of household $(p<0.01)$, and the practice of irrigated farming $(\mathrm{p}<0.05)$. Amongst the significant variables, the coefficients all showed signs that were in agreement with a priori expectations. The probability of an average household to receive food aid in the Lowveld Cattle \& Cotton (LCC) FEZ was found to be $2.2 \%$, whereas the probability of a wealthy household not receiving food aid in the LCC FEZ was found to be $1 \%$. Households that practice irrigated farming in the LCC FEZ were found to be $29 \%$ unlikely to receive food aid.

The results shown in Table 3 reflect that the model has an acceptable level of correct prediction of $94.45 \%$ of overall outcomes. The Hosmer Lameshaw Goodness of fit shows a value of 0.94 which is also above the critical 0.05 . Out of the eight explanatory variables, only one was significant and this was the practice of dryland farming $(\mathrm{p}<0.1)$. Households that practice or produce under rainfed conditions in the HMC FEZ were found to have a probability of $1.2 \%$ of not being considered for food aid distribution.

\section{Factors affecting agricultural production}

The results shown in Table 4 reflect that the multiple regression model is significant $(p<0.01)$ with a coefficient of determination of $51 \%$. Out of the eight explanatory variables, six were found to be significant. These were the employment status of household head $(p<0.01)$, number of members living within the household $(p<0.05)$, type of food aid received $(p<0.1)$, and gender of the household head $(\mathrm{p}<0.05)$. A variable on the actual receipt of food aid by a household in year $\left(\mathrm{t}_{-1}\right)$ was initially included in the model, however in the process of analysis it had to be excluded because of its collinearity with the variable on type of food aid in year $\left(t_{-1}\right)$. Following its exclusion, it was realized that indicators such as the Coefficient of Determination $\left(\mathrm{R}^{2}\right)$, Durbin Watson statistics (DW) and the level of significance of individual variables were subsequently improved.

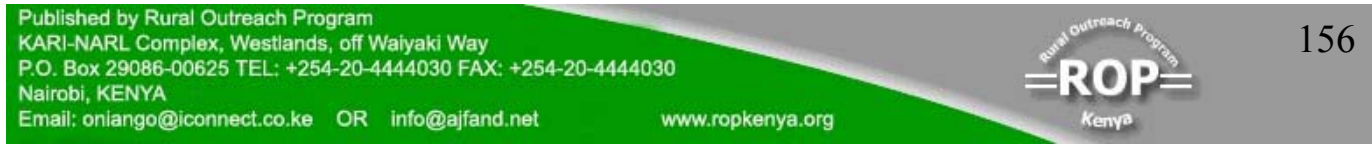




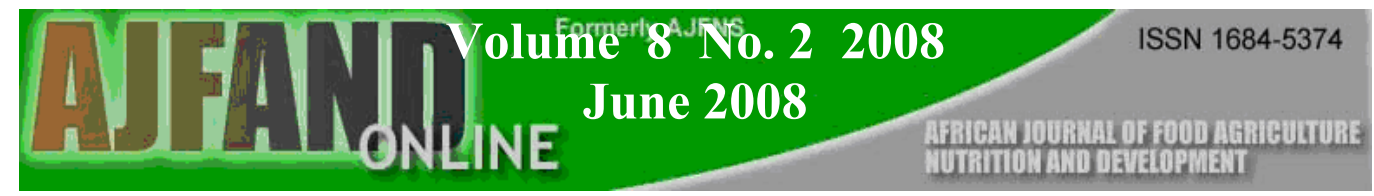

\section{DISCUSSION}

The results in Table 1 imply that having received food aid in the previous year does not on its own influence the decision by households to cultivate their land for production of either food crops or cash crops in both the Lowveld Cattle and Cotton Food Economy Zone (LCC FEZ) and the Highveld Maize and Cattle Food Economy Zone (HMC FEZ).

With regards to the eligibility of households to receive food aid, the results reflect that each FEZ shows different indicators. In the LCC FEZ it was found that as the number of household members increases, their survival on locally produced food is negatively affected, hence food aid has a role to play in filling the food sufficiency gap. Whilst the above remains a reality, it is unfortunate that households that are classified as wealthy tend to be deprived of food aid despite being equally affected as households within the same locality. This could be one major source of conflict within communities on the basis that, ideally, beneficiaries should be identified based on their capacity to produce enough food under the prevailing climatic conditions, and that is in no way related to the ownership of material goods. Households that are engaged in irrigated farming in the LCC FEZ, wherein they tend to produce either food crops or cash crops, are more likely to be food secure than those households who rely on rainfed agriculture, hence they are not normally considered for food aid distribution.

Households located within the HMC FEZ are capable of surviving on locally produced food, hence they are less vulnerable to drought, making them very much unlikely to be considered for food aid interventions. This could be associated with the favourable weather conditions found in the Highveld. Under such conditions, it is expected that, ceteris paribus, planted food crops, particularly maize, have a fair opportunity of reaching maturity, therefore the production of food in a particular household within the HMC FEZ can only be affected by the amount of land cultivated even if it is under rain-fed conditions.

Amongst factors that were presumed to affect agricultural production (of either food crop or cash crop) at household level was the variable on type of food aid received by households. Though the focus was on the literal receipt of food aid, the results, however were able to show that food aid alone has no direct impact on agricultural production but what matters is the mode of delivery to the beneficiaries (free food aid). Food aid is more popular in the Lowveld where the production of maize has been identified as very risky under the current weather conditions. Farmers have been encouraged to shift towards drought tolerant crops but observations made from Figures 1 and 2, and Table 7 reflect that instead of growing such crops, farmers have opted to scale down on their land utilization for agricultural purposes and have also ignored the production of drought tolerant crops whilst they continue to rely on food aid to reduce the food gap.

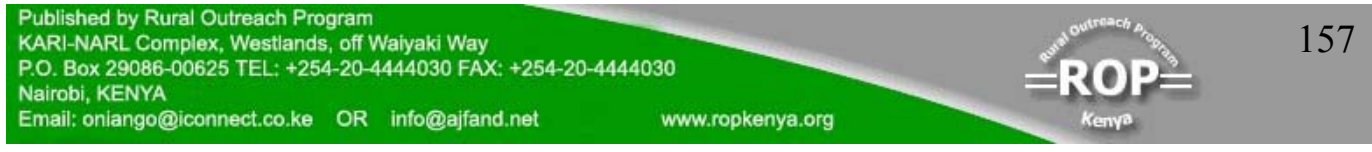




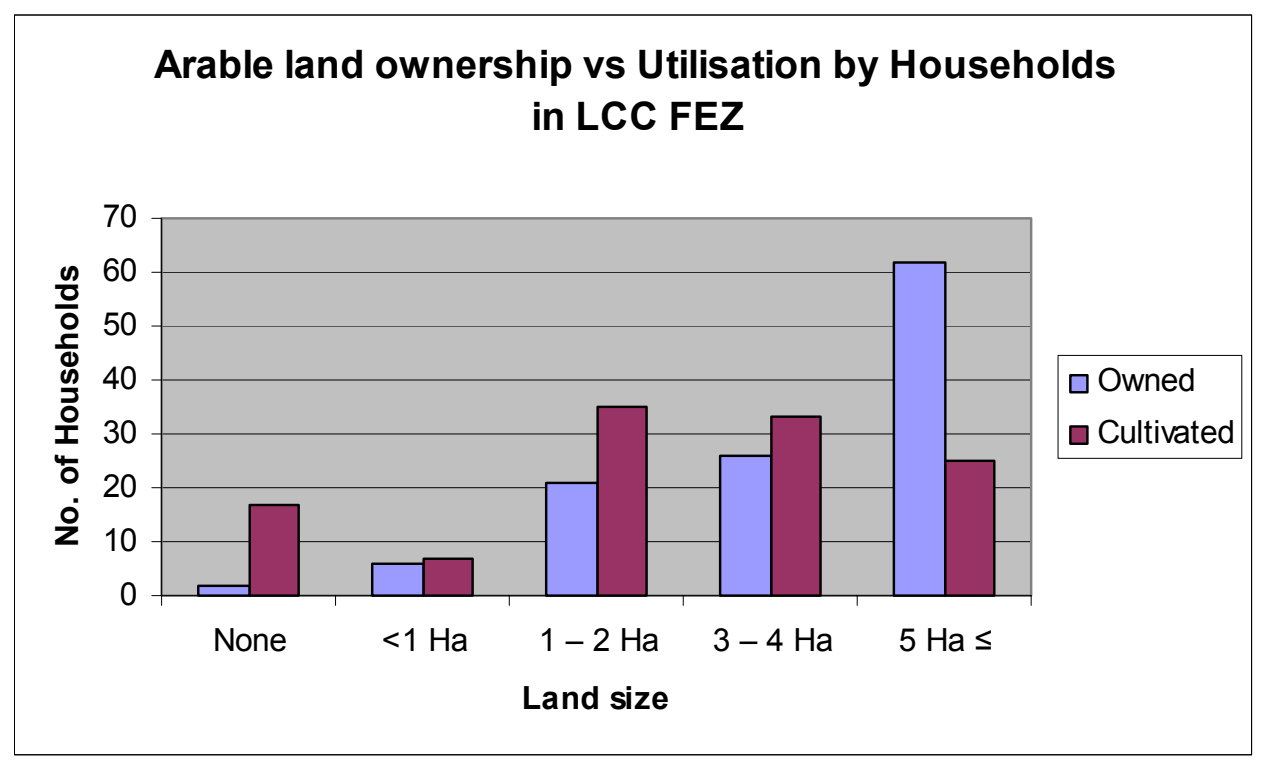

Figure 1: Arable Land Ownership Versus Utilisation in the Lowveld Cattle \& Cotton Food Economy Zone

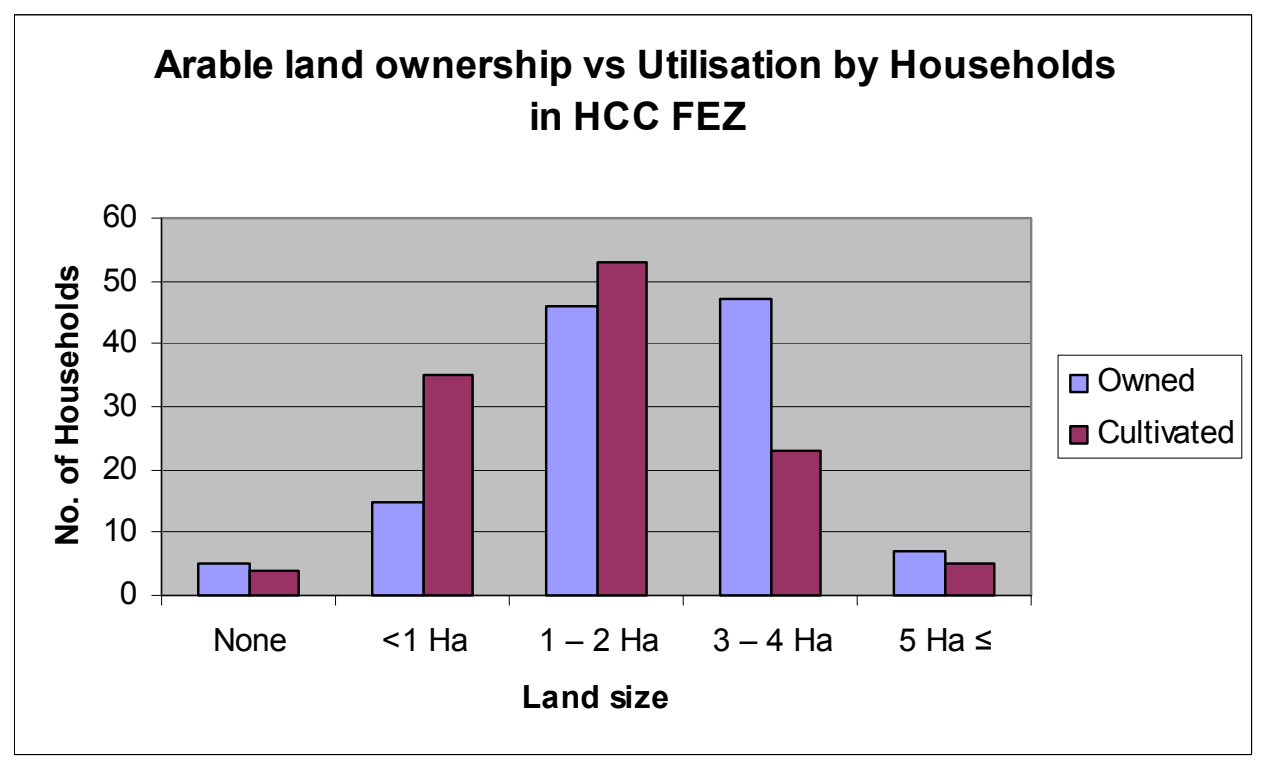

Figure 2: Arable Land Ownership Versus Utilisation in the Highveld Cattle \& Maize Food Economy Zone 


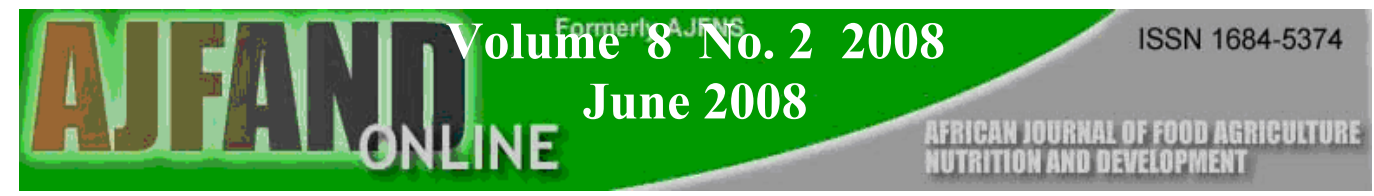

\section{CONCLUSION}

The study was successful in showing that food aid on its own does not have a negative effect on Swaziland's agricultural production at household level. The identification criterion also needs to be looked into as the results have shown that it is not uniform amongst the areas considered during analyses. Improving on the mode of delivery could enhance the utilization of food aid and possibly work towards countering the likelihood of aid creating a dependency syndrome amongst the beneficiaries. Despite the recurring drought problems, farmers have not taken the initiative to plant drought tolerant crops and this is worsening the situation as maize is no longer a viable crop to produce under rain-fed conditions, particularly in the Lowveld Cattle \& Cotton Food Economy Zone.

\section{POLICY RECOMMENDATIONS}

For the sake of sustainability, the Government of Swaziland needs to reconsider the coordination of food aid within its own system. Currently, food aid is coordinated under the disaster programme and since regional forecasts have projected that the current drought is likely to continue for the next ten years, there is a dire need, therefore to develop a long term plan in the form of a food security policy. This policy will address food security issues in a wholistic manner rather than to rely on a programme meant for short-term interventions when infact the effects of drought appear to be perpetual in the country.

The food security policy should also advocate for sustainable food production, which will promote production according to agro-ecological suitability. Farmers should be empowered to produce crops that have been certified suitable for that particular zone (or area) as this would promote production efficiency and also lead to intra trade within the zones.

There is also a need to improve the budget towards irrigation development (in line with regional and international declarations to which the country is a signatory), particularly for areas where the effects of drought are acutely felt. This could be a way of reducing the food gap currently being met through food aid donations.

In the meantime, the issue of targeting needs to be further investigated as it will give a broader picture with regards to errors of inclusion and errors of exclusion. Such a study would, in a way, examine the efficiency of food aid, looking in particular at the relationship between the people who deserve food aid and those who are currently receiving food aid.

\section{ACKNOWLEDGEMENTS}

The authors are grateful for the joint support of the International Foundation for Sciences (IFS) and the United Nations University, Institute for Advanced Studies (UNI-IAS) who made it possible to carry out this research. The Swaziland Government, Ministry of Agriculture \& Cooperatives, is also acknowledged for its institutional support. The AEM department of the University of Swaziland, particularly Dr P.M Dlamini, Dr J.I Rugambisa, and Dr M.M Sithole, are also herewith acknowledged. Last but not least, the authors wish to

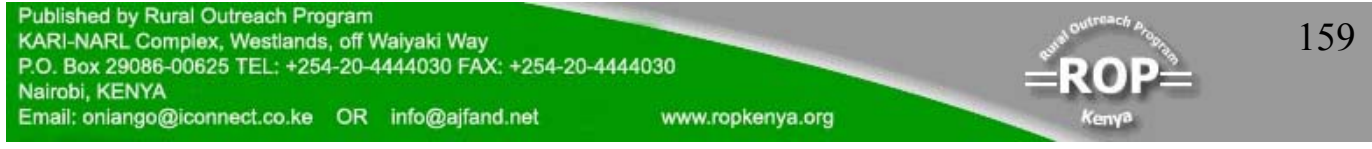




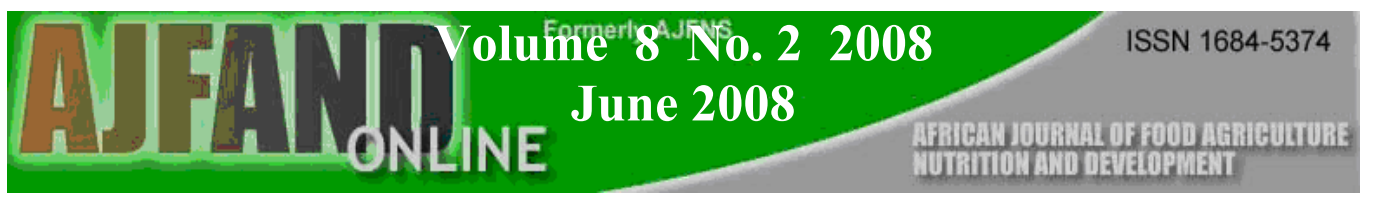

acknowledge the input and commitment of the Research Assistants together with the respondents who are basically the architects of this final piece of work.

Table 1: Independence between Food Aid and Agricultural Production

\begin{tabular}{lccc}
\hline Food Economy & $\begin{array}{c}\text { Land } \\
\text { cultivation in } \\
2004 / 05\end{array}$ & $\begin{array}{c}\text { Production of } \\
\text { any food crop } \\
\text { in } 2004 / 05\end{array}$ & $\begin{array}{c}\text { Production of } \\
\text { any cash crop } \\
\text { in 2004/05 }\end{array}$ \\
\hline $\begin{array}{l}\text { Lowveld FEZ } \\
\text { Pearson } X_{2} \text { (p- value) }\end{array}$ & $0.543^{\text {n.s }}$ & $0.347^{\text {n.s }}$ & $0.742^{\text {n.s }}$ \\
Highveld FEZ & $0.704^{\text {n.s }}$ & $0.758^{\text {n.s }}$ & $0.771^{\text {n.s }}$ \\
Pearson $X_{2}$ (p-value) & & & \\
& & & \\
\hline n.s- Not significant
\end{tabular}




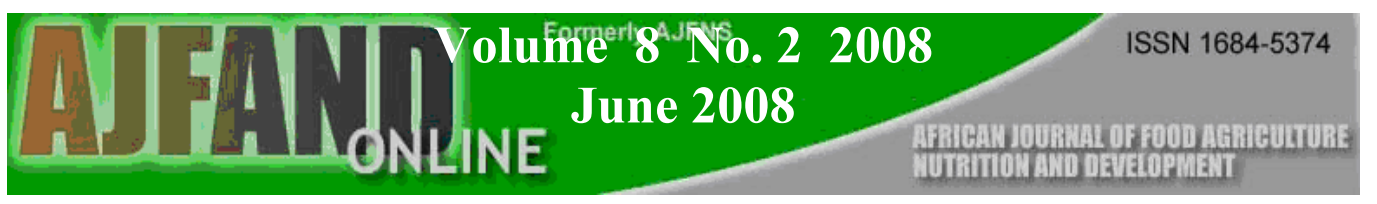

Table 2: Household Eligibility to Receive Food Aid in the Lowveld Cattle \& Cotton Food Economy Zone

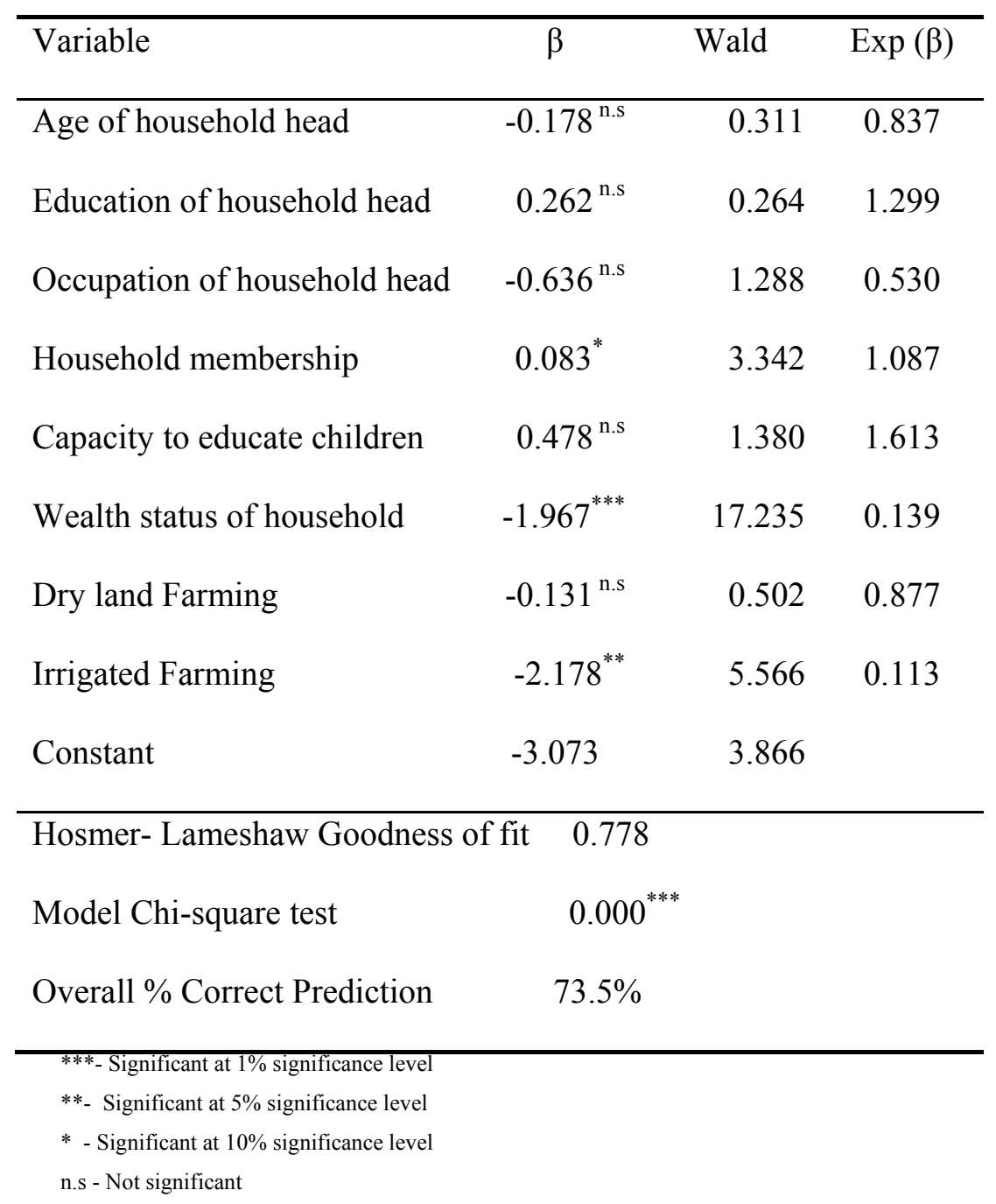




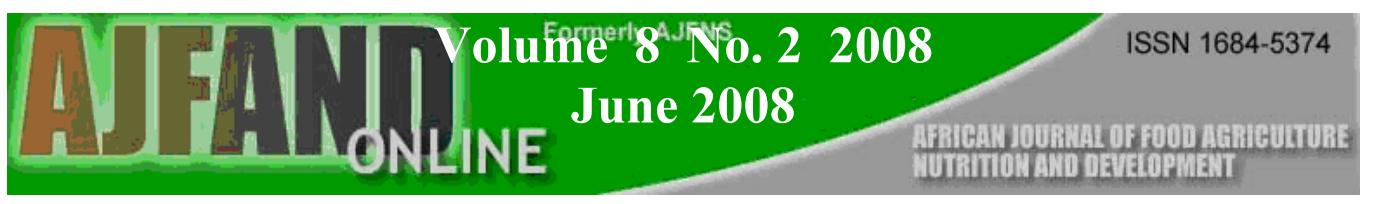

Table 3: Household Eligibility to Receive Food Aid in the Highveld Maize \& Cattle Food Economy Zone

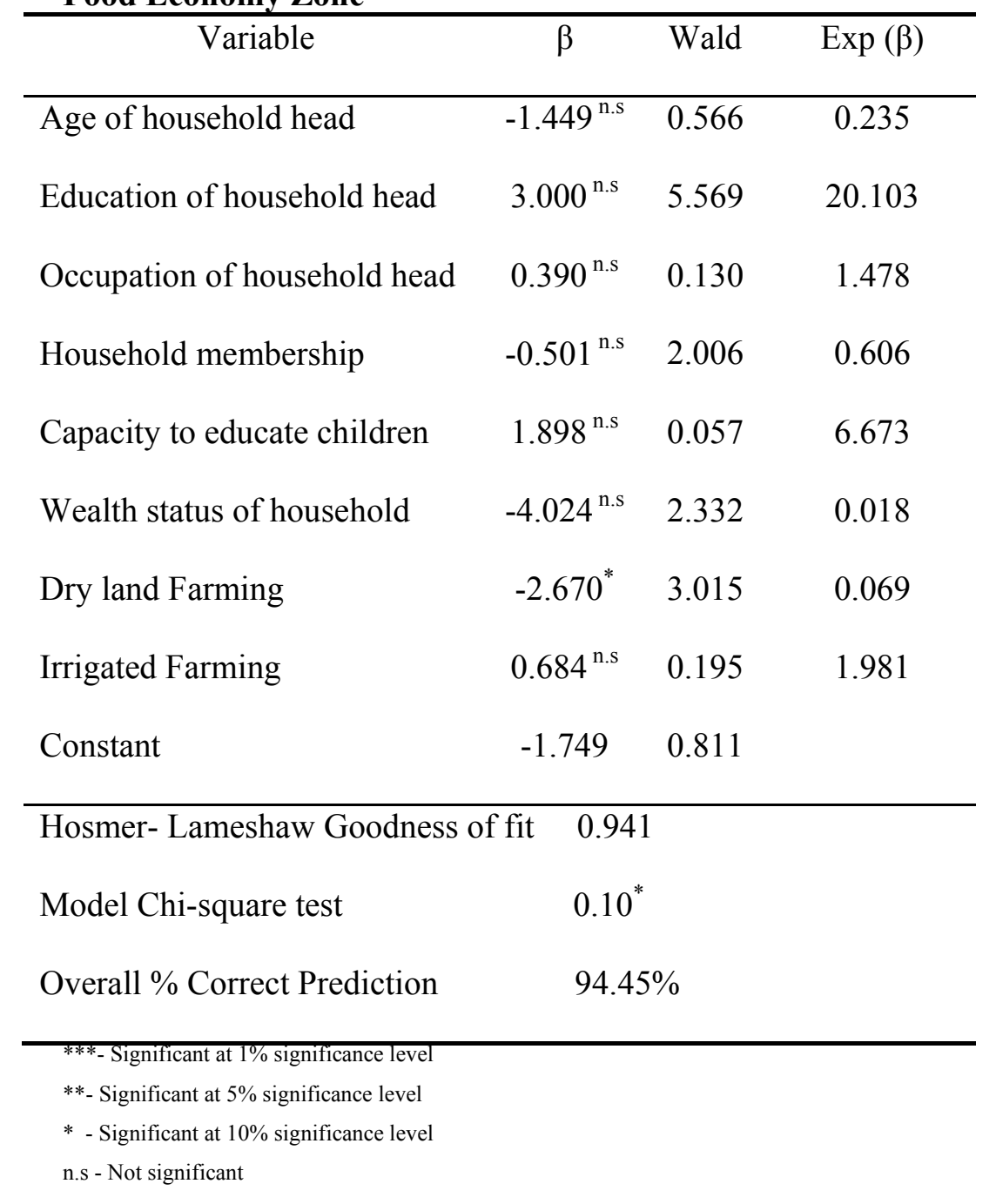


Table 4: $\quad$ Factors affecting Agricultural Production at Household Level in the Lowveld Cattle \& Cotton and Highveld Cattle \& Maize Food Economy Zones

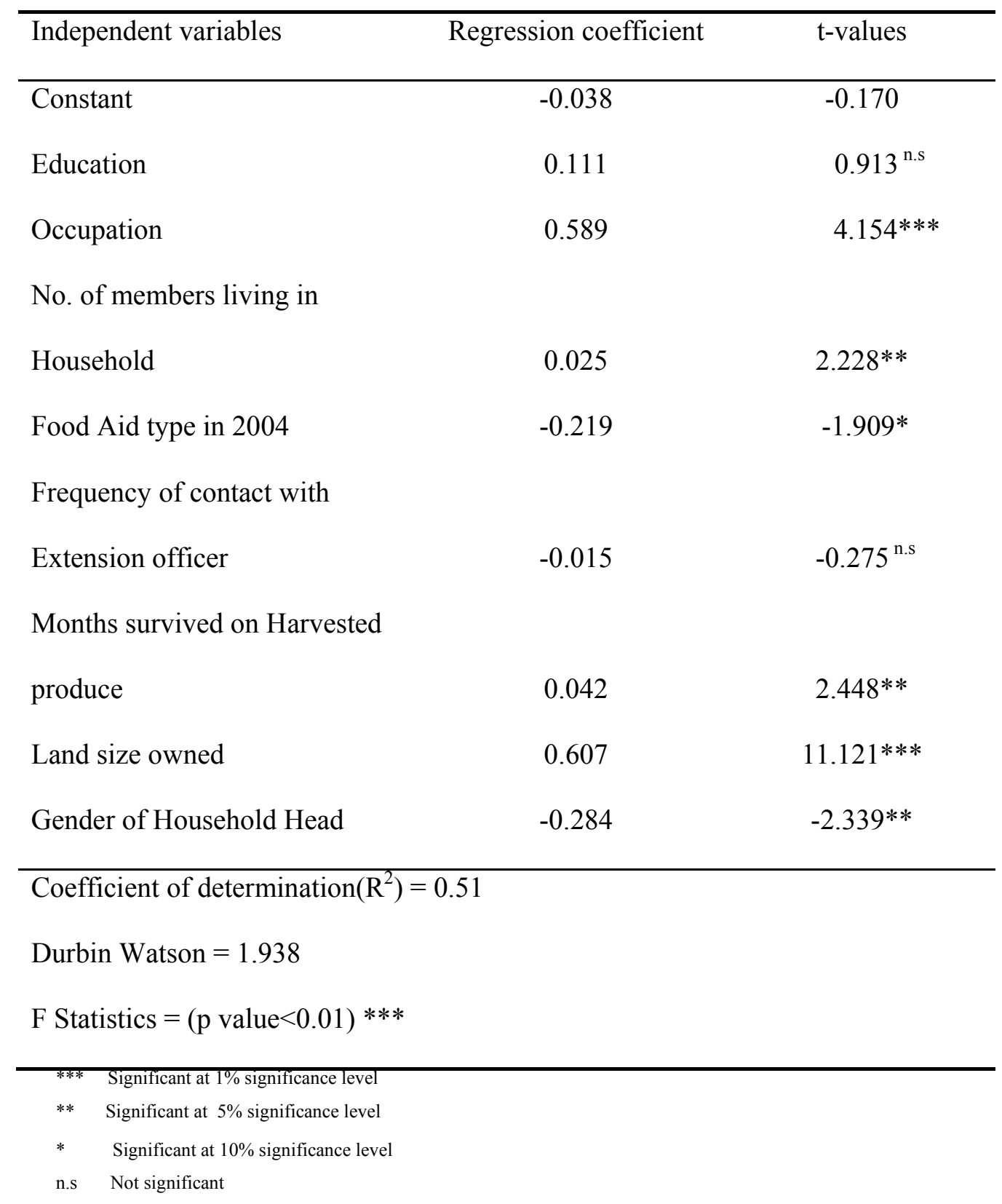


Table 5: $\quad$ Farmer Characteristics for respondents in the Lowveld Cattle \& Cotton and Highveld Cattle \& Maize Food Economy Zones

Sex of Household Heads

\begin{tabular}{lrrr}
\hline FEZ & Male & Female & Total \\
LCC & 88 & 29 & 117 \\
HCM & 81 & 39 & 120 \\
\hline Total & 169 & 68 & 237 \\
\hline
\end{tabular}

Ages of Household Heads

\begin{tabular}{lrrrr}
\hline FEZ & $21-25$ & $36-50$ & $51 \&$ above & Total \\
LCC & 13 & 52 & 52 & 117 \\
HCM & 6 & 32 & 82 & 120 \\
\hline Total & 19 & 84 & 134 & 237 \\
\hline
\end{tabular}

Education levels of Household Heads

\begin{tabular}{lrrrrrr}
\hline FEZ & $\begin{array}{r}\text { No formal } \\
\text { education }\end{array}$ & $\begin{array}{r}\text { Primary } \\
\text { school }\end{array}$ & $\begin{array}{r}\text { Secondary } \\
\text { school }\end{array}$ & O'level & Tertiary & Total \\
\hline LCC & 51 & 39 & 16 & 6 & 5 & 117 \\
HCM & 30 & 45 & 22 & 15 & 8 & 120 \\
\hline Total & 81 & 84 & 38 & 21 & 13 & 237 \\
\hline
\end{tabular}

Occupation of Household Heads

\begin{tabular}{lrrrr}
\hline FEZ & $\begin{array}{r}\text { Full time } \\
\text { Farmer }\end{array}$ & $\begin{array}{r}\text { Non-Farm } \\
\text { Employment }\end{array}$ & Unemployed & Total \\
\hline LCC & 31 & 27 & 59 & 117
\end{tabular}




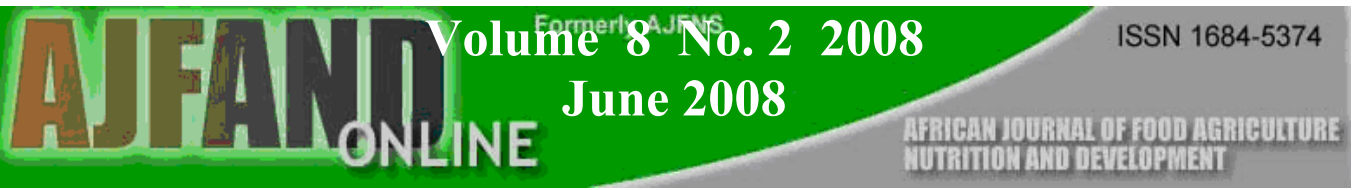

\begin{tabular}{lrrrr} 
HCM & 18 & 36 & 66 & 120 \\
\hline Total & 49 & 63 & 125 & 237 \\
\hline
\end{tabular}

Number of members residing in Households

\begin{tabular}{llrr}
\hline $\begin{array}{l}\text { Household } \\
\text { members }\end{array}$ & LCC & Households & Total \\
\cline { 2 - 4 } $1-5$ & 21 & 32 & 53 \\
$6-10$ & 60 & 60 & 120 \\
$11-15$ & 22 & 21 & 43 \\
$16-20$ & 11 & 7 & 18 \\
$21-25$ & 1 & 0 & 1 \\
$26-30$ & 0 & 0 & 0 \\
$31-35$ & 1 & 0 & 1 \\
$36-40$ & 0 & 0 & 0 \\
$41-45$ & 0 & 0 & 0 \\
$46-50$ & 1 & 0 & 1 \\
\hline Total & 117 & 120 & 237 \\
\hline
\end{tabular}


Table 6: Access to irrigation by Households in the Lowveld Cattle \& Cotton and Highveld Cattle \& Maize Food Economy Zones

Access to irrigation by Household

\begin{tabular}{lrrr}
\hline FEZ & With access & Without access & Total \\
\hline LCC & 7 & 110 & 117 \\
HCM & 20 & 100 & 120 \\
\hline Total & 27 & 210 & 237 \\
\hline
\end{tabular}

Area under irrigation

\begin{tabular}{rrrrrrr}
\hline FEZ & None & $<$ ha & $1-2$ ha & $3-4$ ha & 5 ha $\leq$ & \multicolumn{2}{c}{ Total } \\
\hline LCC & 107 & 2 & 1 & 4 & 3 & 117 \\
HCM & 100 & 18 & 1 & 1 & 0 & 120 \\
\hline Total & 207 & 20 & 2 & 5 & 3 & 237
\end{tabular}


Table 7: Major Crops Produced and their Scale of Production in the HCM and LCC FEZs

\begin{tabular}{|c|c|c|c|c|c|c|}
\hline \multirow{2}{*}{$\begin{array}{l}\text { Food } \\
\text { Economy } \\
\text { Zone }\end{array}$} & \multicolumn{6}{|c|}{ Area under Maize } \\
\hline & None & $<1 \mathrm{Ha}$ & $1-2 \mathrm{Ha}$ & $3-4 \mathrm{Ha}$ & $5 \mathrm{Ha} \leq$ & Total \\
\hline $\mathrm{LCC}$ & 23 & 10 & 42 & 34 & 8 & 117 \\
\hline HCM & 3 & 43 & 55 & 16 & 3 & 120 \\
\hline Total & 26 & 53 & 97 & 50 & 11 & 237 \\
\hline Food & \multicolumn{6}{|c|}{ Area under Sorghum } \\
\hline $\begin{array}{l}\text { Economy } \\
\text { Zone }\end{array}$ & None & $<1 \mathrm{Ha}$ & $1-2 \mathrm{Ha}$ & $3-4 \mathrm{Ha}$ & $5 \mathrm{Ha} \leq$ & Total \\
\hline LCC & 112 & 2 & 3 & 0 & 0 & 117 \\
\hline $\mathrm{HCM}$ & 119 & 1 & 0 & 0 & 0 & 120 \\
\hline Total & 231 & 3 & 3 & 0 & 0 & 237 \\
\hline Food & \multicolumn{6}{|c|}{ Area under Cotton } \\
\hline $\begin{array}{l}\text { Economy } \\
\text { Zone }\end{array}$ & None & $<1 \mathrm{Ha}$ & $1-2 \mathrm{Ha}$ & $3-4 \mathrm{Ha}$ & $5 \mathrm{Ha} \leq$ & Total \\
\hline $\mathrm{LCC}$ & 80 & 1 & 11 & 21 & 4 & 117 \\
\hline $\mathrm{HCM}$ & 120 & 0 & 0 & 0 & 0 & 120 \\
\hline Total & 200 & 1 & 11 & 21 & 4 & 237 \\
\hline Food & \multicolumn{6}{|c|}{ Area under Vegetables } \\
\hline $\begin{array}{l}\text { Economy } \\
\text { Zone }\end{array}$ & None & $<1 \mathrm{Ha}$ & $1-2 \mathrm{Ha}$ & $3-4 \mathrm{Ha}$ & $5 \mathrm{Ha} \leq$ & Total \\
\hline $\mathrm{LCC}$ & 108 & 6 & 2 & 1 & 0 & 117 \\
\hline $\mathrm{HCM}$ & 91 & 28 & 0 & 0 & 1 & 120 \\
\hline Total & 199 & 34 & 2 & 1 & 1 & 237 \\
\hline Food & \multicolumn{6}{|c|}{ Area under Cassava } \\
\hline $\begin{array}{l}\text { Economy } \\
\text { Zone }\end{array}$ & None & $<1 \mathrm{Ha}$ & $1-2 \mathrm{Ha}$ & $3-4 \mathrm{Ha}$ & $5 \mathrm{Ha} \leq$ & Total \\
\hline LCC & 116 & 1 & 0 & 0 & 0 & 117 \\
\hline $\mathrm{HCM}$ & 120 & 0 & 0 & 0 & 0 & 120 \\
\hline Total & 236 & 1 & 0 & 0 & 0 & 237 \\
\hline
\end{tabular}




\section{REFERENCES}

1. Reutlinger S From Food Aid To Aid For Food: Into the $21^{\text {st }}$ Century. Food Policy 1999; 24: 7 -15.

2. Christiensen $\mathbf{C}$ The New Policy Environment For Food Aid: The Challenge For sub-Saharan Africa. Food Policy 2000; 25: 255 - 268.

3. Ingco MD, Mitchell D and JD Nash Food Security and Agricultural Trade Policy Reform. In: Ingco MD and JD Nash (Ed). Agriculture and the WTO: Creating a Trading System for Development. World Bank, Washington DC, 2004: 179 - 192.

4. Clark CS Food Aid in WTO Agricultural Trade Policy. Canadian Foodgrains Bank, 2001.

5. Dorosh PA, Ninno $\mathbf{C}$ and K Subbarao Food Aid and Food Security in the Short and Long Run: Country Experience from Asia and sub-Saharan Africa. World Bank Discussion Paper, 2005; 0538.

6. Tschirley D and J Howard Title II Food Aid and Agricultural Development in subSaharan Africa: Towards a Principal Argument for When not to Monetize. MSU International Development Working Paper, Department of Agricultural Economics, Michigan State University, 2003; 81.

7. Lavy V Does Food Aid Depress Food Production? The Disincentive Dilemma in the African Context. World Bank Working Paper, 1990; 0460.

8. Abdulai A, Barrett B and $\mathbf{J}$ Hoddinott Does Food Aid Really Have Disincentive Effects? New Evidence from sub-Saharan Africa. Cornell University, Working Paper, 2004.

9. WFP/FAO. Food Supply Assessment Mission to Swaziland. Rome, 2005.

10. SADC HIV/AIDS in SADC- Fact Sheet. SADC HIV/AIDS Unit, Gaborone, 2004.

11. Tapio-Bistrom ML Food Aid and the Disincentive Effect in Tanzania. University of Helsinki Publication, Agricultural Policy 2001; 31: pp 115.

12. Government of Swaziland Constraints Affecting Smallholder Agricultural Development in Swaziland. Ministry of Agriculture and Cooperatives, Mbabane, 1996.

13. Swaziland National Vulnerability Committee Swaziland Livelihood Based Vulnerability Assessment, Mbabane, 2003. 
14. Mason RD and AL Lind Statistical Techniques in Business and Economics. McGraw Hill, $9^{\text {th }}$ Edition, 1996.

15. Thamaga-Chitja JM, Hendriks SL, Ortmann GF and M Green Impact of Maize Storage on Rural Household Food Security in Northern KwaZulu Natal. Family Ecology and Consumer Science 2004; 32: 8 - 15.

16. Zegeye T, Tadessee B and S Tesfaye Determinants of Adoption of Improved Maize Technologies in Major Maize Growing Regions of Ethiopia. $2^{\text {nd }}$ Maize Workshop of Ethiopia, Addis Ababa, 2001.

17. Demeke M, Guta $\mathbf{F}$ and $\mathbf{T}$ Federe Agricultural Development in Ethiopia: Are There Alternatives to Food Aid? Department of Economics, Addis Ababa University, 2004. 